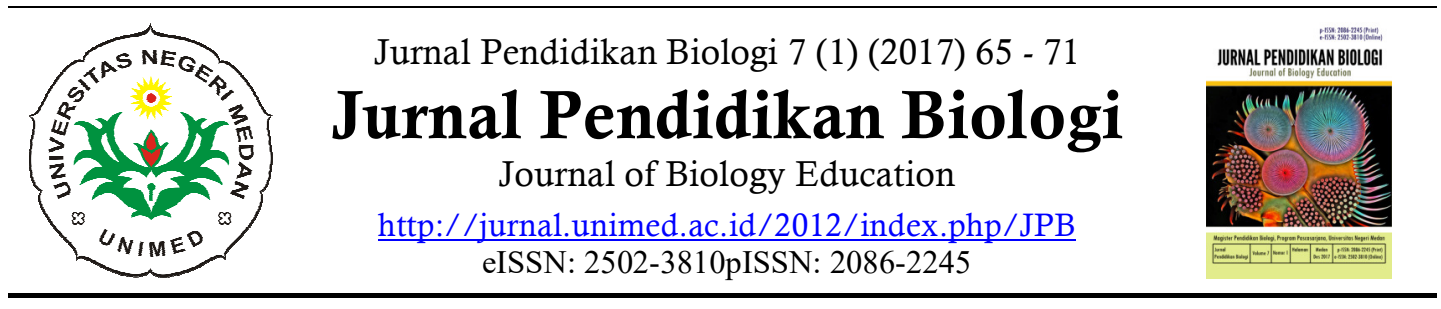

\title{
Pengaruh Model Pembelajaran Learning Cycle dan Problem Based Learning terhadap Hasil Belajar Siswa pada Materi Ekosistem
}

\author{
Masni Veronika Situmorang* \\ SMP Swasta Methodist Pematangsiantar, Kotamadya Pematangsiantar, Sumatera Utara \\ *Korespondensi: masniveronika@gmail.com
}

\begin{abstract}
This research was conducted in class $7^{\text {th }}$ SMP Swasta Methodist Pematangsiantar which aims to determine: The effect of learning model (Learning Cycle, Problem Based Learning, and Konvensional) on student's learning outcomes in ecosystem material. The population in this study amounted four classes and otherwise being research sample was as much as three classes, $7^{\text {th }}$-A as class with Problem Based Learning, $7^{\text {th }}$ - B as class with Learning Cycle, and $7^{\text {th }}-\mathrm{C}$ as class with Konvensional. The data collection instrument by using: Test student's learning outcomes in the form of the 30 multiplechoice items. This research method is quasi experiment with data analysis technique using Anacova Test and Anova 2 lines with a significance level $\alpha=0,05$. The result of this research found that: There is an effect of learning model (Learning Cycle, Problem Based Learning, and Konvensional) on student's learning outcomes in ecosystem material, where a group of student who learned wih

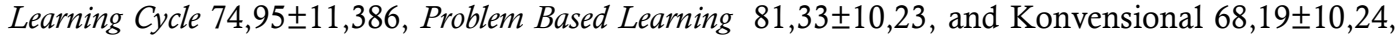
with $\mathrm{F}_{\text {count }}=13,280 ; p=0,000$ and significance level $\alpha=0,05$.
\end{abstract}

Keywords: Learning Cycle, Problem Based Learning, Learning Outcomes

\section{PENDAHULUAN}

Pembelajaran ekosistem yaitu belajar mengenai hubungan timbal balik makhluk hidup dengan lingkungannya. Untuk mempelajarinya, siswa perlu diberikan pembelajaran yang baik. Reyna (2011) menjelaskan bahwa pembelajaran ekosistem di Australia dilakukan dengan sistem e-learning. Disini siswa dibelajarkan secara aktif, adanya interaksi antara siswa dengan guru sehingga siswa pun merasa terlibat dalam proses pembelajaran.
Selain sistem e-learning atau pembelajaran online, pembelajaran ekosistem seharusnya dilakukan langsung di alam. Namun yang terjadi di SMP Swasta Methodist Pematangsiantar berdasarkan hasil observasi bahwa pembelajaran yang dilakukan masih menggunakan ceramah. Cara seperti ini kurang efektif, ini terbukti bahwa Standar Ketuntasan Belajar Mengajar (SKBM) untuk mata pelajaran IPA di sekolah ini adalah 70. Sebaliknya nilai rata-rata perolehan siswa adalah 65 . 
Kegiatan pembelajaran yang selama ini dilaksanakan di sekolah tersebut kebanyakan masih dalam bentuk pembelajaran yang berpusat pada guru bukan pada siswa. Pembelajaran ini lebih mengutamakan bagaimana cara mengisi pikiran siswa bukan pada bagaimana cara menata berpikir. Pembelajaran menjadi pasif dan tidak ada kerja sama antar siswa bahkan antara guru dan siswa, sehingga siswa kehilangan kemampuan dirinya, toleransi terhadap perbedaan pendapat dan pengambilan keputusan yang bertanggung jawab. Akibat yang lain yang dapat ditimbulkan yaitu siswa menjadi kerdil dan tidak dapat mengembangkan kreativitas belajar mereka secara optimal dan bertanggung jawab.

Dari uraian di atas, dapat dipahami bahwa untuk meningkatkan hasil belajar siswa, dibutuhkan suatu model atau strategi pembelajaran yang mampu untuk lebih memberdayakan siswa dalam suatu proses pembelajaran. Guru dapat menghubungkan permasalahan tersebut dengan konsepkonsep pembelajaran dan pada akhirnya siswa dapat mengaplikasikan konsepkonsep tersebut dalam memecahkan berbagai masalah yang dihadapinya. Dari sekian banyak model pembelajaran yang bisa digunakan, penulis menggunakan pembelajaran Learning Cycle karena memiliki kelebihan antara lain: (1) merangsang kembali siswa untuk mengingat kembali materi pelajaran yang telah mereka dapatkan sebelumnya; (2) memberikan motivasi kepada siswa untuk lebih aktif dalam pembelajaran dan menambah rasa keingintahuan; (3) melatih siswa belajar menemukan konsep melalui kegiatan eksperimen; (4) melatih siswa untuk menyampaikan secara lisan konsep yang telah mereka pelajari; dan (5) memberi kesempatan kepada siswa untuk berpikir, mencari, menemukan dan menjelaskan contoh penerapan konsep yang telah dipelajari.

Dahar (1988) mengemukakan bahwa Learning Cycle adalah suatu strategi pembelajaran yang berpusat pada pebelajar (student centered). Pada prinsipnya Learning Cycle merupakan rangkaian tahap-tahap kegiatan yang diorganisasikan sedemikian rupa sehingga pebelajar dapat menguasai kompetensi-kompetensi yang harus dicapai dalam pembelajaran dengan jalan berperan aktif. Strategi ini memudahkan siswa memahami materi secara bermakna, karena guru telah membuat materi pelajaran terorganisasi dengan baik dan diberikan sebelum belajar di kelas. Sebagai alat bantu proses desain instruksional, Learning Cycle dapat memperkuat kognitif siswa dan meningkatkan pemahaman siswa tentang berbagai materi pelajaran. Hal ini sesuai dengan penelitian yang dilakukan oleh Suastika (2011) bahwa pembelajaran Learning Cycle dapat meningkatkan hasil belajar. Pembelajaran lebih dominan pada tahap eksplorasi dimana siswa melakukan pengamatan dan percobaan, dan juga pada tahap penjelasan dimana guru meminta penjelasan siswa terlebih dahulu kemudian guru mengembangkan konsep yang telah didapatkan siswa sehingga siswa lebih memahami konsep tersebut.

Selain itu, dapat pula digunakan Problem Based Learning. Pembelajaran ini merupakan salah satu strategi yang dapat meningkatkan aktivitas siswa dalam belajar. Aktivitas tersebut cenderung lebih ringkas, terbuka, dan mudah untuk berintegrasi dan diorganisasikan dengan pelajaran sebelumnya. Menurut Simmons, et.al. (2008) proses PBL merupakan pendekatan pembelajaran yang berpusat pada pebelajar dimana siswa dapat mengadakan pengamatan, mengintegrasi 
antara teori dan praktek, dan aplikasi atau penerapan pengetahuan, pengembangan keterampilan untuk mencari solusi dari suatu masalah. Lebih lanjut Akcay (2009) mengemukakan bahwa PBL membuat siswa lebih aktif, karena mereka diberikan satu masalah sehingga mereka merasa lebih memiliki wewenang dan tanggung jawab dalam tugas mereka.

Permasalahan yang dikaji dalam penelitian ini adalah: hasil belajar siswa, dalam penelitian ini dibatasi dalam ranah kognitif pada materi ekosistem di kelas VII SMP yang diperoleh melalui tes hasil belajar. Tujuan penelitian ini dilakukan adalah untuk mengetahui perbedaan pengaruh model pembelajaran (Learning Cycle, Problem Based Learning, dan Konvensional) terhadap hasil belajar siswa pada materi ekosistem.

\section{METODE PENELITIAN}

Rancangan penelitian ini adalah quasi eksperimen, yang dilakukan terdiri dari dua kelompok eksperimen (Learning Cycle dan Problem Based Learning) dan satu kelompok kontrol (Konvensional), dilaksanakan di SMP Swasta Methodist Pematangsiantar. Waktu penelitian mulai bulan Februari sampai Mei 2014. Validasi instrumen penelitian dilakukan oleh 2 orang ahli, kemudian uji coba instrumen pada 35 orang siswa kelas VII.

Teknik pengumpulan data pada penelitian ini berupa tes hasil belajar. Sebelumnya data yang diperoleh dilakukan uji persyaratan yang terdiri dari uji normalitas data menggunakan Uji Liliefors dan uji homogenitas data menggunakan Levene's Test pada taraf signifikansi 0,05 . Uji normalitas yang dilakukan dengan asumsi bahwa data hasil belajar bersifat normal; sedangkan uji homogenitas dilakukan dengan asumsi bahwa data hasil belajar bersifat homogen. Selanjutnya, dilakukan uji anakova dengan taraf signifikansi 0,05. Analisis data penelitian dilakukan dengan menggunakan software Systat 13.0 dan SPSS 19.0. Sedangkan untuk menguji hipotesis penelitian antara kelompok pembelajaran menggunakan model pembelajaran Learning Cycle, Problem Based Learning, dan pembelajaran konvensional yang dievaluasi menggunakan uji ANACOVA pada taraf signifikansi $\alpha=$ 0,05 .

\section{HASIL DAN PEMBAHASAN}

Nilai hasil belajar terentang dari skor 0-100. Data hasil belajar (pretes) yang dibelajarkan dengan model pembelajaran Problem Based Learning $\mathrm{N}=35$ orang diperoleh data nilai rata-rata hasil belajar sebesar $=49,05$, dengan nilai minimum $=$ 33,33 ; nilai maksimum $=60,00$; nilai median $=50,00 ;$ standar deviasi $=7,075$. Untuk data hasil belajar (postes) yang dibelajarkan dengan model pembelajaran Problem Based Learning $\mathrm{N}=35$ orang diperoleh data nilai rata-rata hasil belajar sebesar $=81,33$, dengan nilai minimum $=$ 53,33; nilai maksimum $=96,67$; nilai median $=83,33 ;$ standar deviasi $=10,23$.

Selanjutnya data hasil belajar (pretes) yang dibelajarkan dengan model pembelajaran Learning Cycle $\mathrm{N}=35$ orang diperoleh data nilai rata-rata hasil belajar sebesar $=47,62$, dengan nilai minimum $=$ 30,00 ; nilai maksimum $=60,00$; nilai median $=50,00 ;$ standar deviasi $=7,94$. Untuk data hasil belajar (postes) yang dibelajarkan dengan model pembelajaran Learning Cycle $\mathrm{N}=35$ orang diperoleh data nilai rata-rata hasil belajar sebesar $=75,05$, dengan nilai minimum $=43,33$; nilai maksimum $=93,33 ;$ nilai median $=76,67$; 
standar deviasi $=11,39$. Sedangkan data hasil belajar yang dibelajarkan dengan model pembelajaran Konvensional $\mathrm{N}=35$ orang diperoleh data nilai rata-rata hasil belajar sebesar $=47,52$, dengan nilai minimum $=33,33 ;$ nilai maksimum $=$ 63,33; nilai median $=50,00 ;$ standar deviasi $=7,56$. Data hasil belajar (postes) yang dibelajarkan dengan model pembelajaran Konvensional $\mathrm{N}=35$ orang diperoleh data nilai rata-rata hasil belajar sebesar $=68,20$, dengan nilai minimum $=46,67$; nilai maksimum $=90,00 ;$ nilai median $=70,00$; standar deviasi $=10,23$.
Data hasil belajar siswa (pretes) berdistribusi normal $(Z=0,168 ; p=0,614)$. Demikian pula untuk data hasil belajar siswa (postes) berdistribusi normal $(\mathrm{Z}=0,159 ; \quad p=0,483)$. Hasil belajar yang dibelajarkan dengan model pembelajaran Learning Cycle $74,95 \pm 11,386 \quad(\bar{x} \pm \mathrm{SD})$ berbeda signifikan dengan hasil belajar yang dibelajarkan dengan model pembelajaran Problem Based Learning $81,33 \pm 10,23$. Demikian pula dengan hasil belajar yang dibelajarkan dengan konvensional $68,19 \pm 10,24$ seperti yang disajikan dalam Gambar 1.

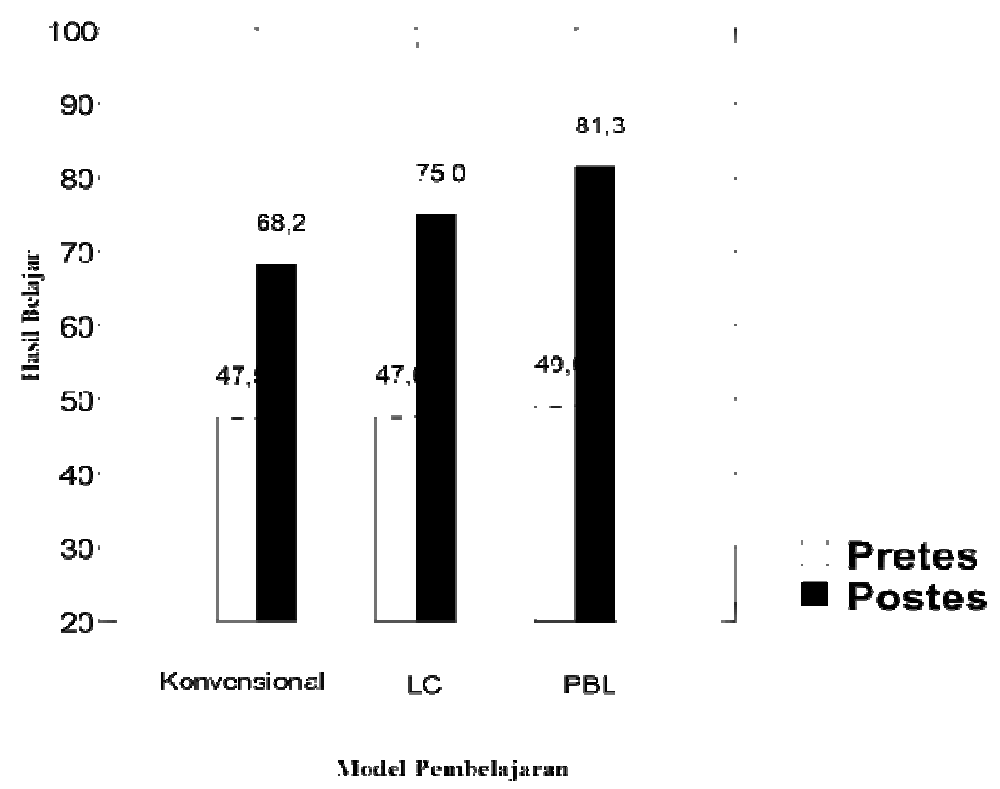

Gambar 1. Pengaruh Model Pembelajaran Learning Cycle dan Problem Based Learning terhadap Hasil Belajar Siswa

Selanjutnya berdasarkan uji Tukey diperoleh bahwa hasil belajar siswa yang dibelajarkan dengan model pembelajaran Learning Cycle $(74,936)$ berbeda signifikan dengan hasil belajar siswa yang dibelajarkan dengan model pembelajaran Problem Based Learning (81,371) dan Konvensional $(68,169)$. Hasil Anakova data pengaruh model pembelajaran
(Learning Cycle, Problem Based Learning, dan Konvensional) adalah $\mathrm{F}_{\text {hitung }}=13,280$; dengan taraf signifikansinya $=0,05$, yang berarti $\mathrm{H}_{0}$ yang menyatakan bahwa tidak ada pengaruh model pembelajaran (Learning Cycle, Problem Based Learning, dan Konvensional) terhadap hasil belajar siswa pada materi ekosistem ditolak; sedangkan Ha yang menyatakan bahwa ada pengaruh 
model pembelajaran (Learning Cycle, Problem Based Learning, dan Konvensional) terhadap hasil belajar siswa pada materi ekosistem diterima.

Pada hasil penelitian diperoleh bahwa ada pengaruh model pembelajaran terhadap hasil belajar siswa. Hal ini ditandai dari rata-rata hasil belajar siswa yang dibelajarkan dengan model pembelajaran Learning Cycle berbeda signifikan dengan rata-rata hasil belajar siswa yang dibelajarkan dengan model pembelajaran Problem Based Learning dan Konvensional.

Siswa yang dibelajarkan dengan model pembelajaran Problem Based Learning memiliki rata-rata hasil belajar yang lebih tinggi dibandingkan dengan siswa yang dibelajarkan dengan model pembelajaran Learning Cycle dan Konvensional. Hal ini dikarenakan siswa dapat: (1) belajar dalam kelompok-kelompok kecil, (2) Diajak untuk menghadapi berbagai situasi kehidupan nyata yang tidak dapat diberi jawaban-jawaban sederhana, dan (3) menganalisis dan menetapkan masalahnya, mengembangkan hipotesis dan membuat prediksi, mengumpulkan dan menganalisis informasi, melaksanakan eksperimen, membuat inferensi dan menarik kesimpulan (Arends, 2008).

Dengan menggunakan model pembelajaran Problem Based Learning siswa baik secara pribadi maupun kelompok dapat menemukan sendiri konsep-konsep pembelajaran melalui pemecahan masalah, siswa merasa terlibat langsung dalam kegiatan belajar-mengajar sehingga dapat meningkatkan hasil belajar. Pembelajaran yang diatur dalam kerja kelompok dalam rangka pemecahan masalah mampu menunjukkan hasil belajar yang lebih baik karena pengkonstruksian pengetahuan dilakukan secara bersama-sama yang memungkinkan siswa dapat mengungkapkan gagasan, mendengarkan pendapat orang lain, dan secara bersamasama membangun pengertian. Pembelajaran berkembang jika peserta didik berpartisipasi aktif dalam proses tersebut dan jika pembelajaran didasarkan pada suatu masalah. Dengan pengajuan masalah dalam konteks dunia nyata, maka siswa secara aktif dapat mengembangkan materi pelajaran yang dibrikan sehingga dapat meningkatkan hasil belajar biologi siswa. hal ini sejalan dengan penelitian yang dilakukan oleh Setiawan (2008) yang menyimpulkan bahwa Problem Based Learning dapat meningkatkan hasil belajar siswa dalam pembelajaran biologi. Temuan dalam penelitian ini juga mendukung penelitian yang dilakukan oleh Sitepu (2011) bahwa pembelajaran Problem Based Learning dapat meningkatkan hasil belajar biologi siswa secara signifikan.

Berbeda dengan model pembelajaran Problem Based Learning, model pembelajaran Learning Cycle yang dilaksanakan juga dapat meningkatkan hasil belajar siswa. Hal ini dapat dilihat dari rata-rata hasil belajar siswa yang dibelajarkan dengan model pembelajaran Learning Cycle yang berbeda dengan ratarata hasil belajar siswa yang dibelajarkan dengan Konvensional.

Learning Cycle adalah model pembelajaran yang berpusat pada pebelajar, dimana memiliki serangkaian tahapan yang diorganisasi sedemikian rupa sehingga pebelajar dapat menguasai kompetensi-kompetensi yang harus dicapai dalam pembelajaran dengan jalan berperan aktif. Bila dikembangkan dan dipelajari lebih lanjut, pembelajaran Learning Cycle dapat meningkatkan hasil belajar karena sesuai dengan teori belajar Piaget. Dahar (1988) menjelaskan pernyataan Piaget 
yang menyatakan bahwa belajar merupakan pengembangan aspek kognitif yang meliputi struktur, isi, dan fungsi. Struktur intelektual adalah organisasiorganisasi mental tingkat tinggi yang dimiliki individual untuk memecahkan masalah-masalah. Isi adalah perilaku khas individu dalam merespon masalah yang dihadapi. Sedangkan fungsi merupakan proses pengembangan intelektual yang mencakup adaptasi dan organisasi. Adaptasi terdiri atas asimilasi dan akomodasi. Pada proses asimilasi individu menggunakan struktur kognitif yang sudah ada untuk memberikan respon terhadap rangsangan yang diterimanya. Dalam asimilasi individu berinteraksi dengan data yang ada di lingkungan untuk diproses dalam struktur mentalnya. Dalam proses ini struktur mental individu dapat berubah, sehingga terjadi akomodasi. Pemerolehan konsep baru akan berdampak pada konsep yang telah dimiliki individu. Individu harus dapat menghubungkan konsep yang baru dipelajari dengan konsep-konsep lain dalam suatu hubungan antar konsep.

Dengan demikian proses pembelajaran bukan lagi sekedar transfer pengetahuan dari guru ke siswa, tetapi merupakan proses pemerolehan konsep yang berorientasi pada keterlibatan siswa secara aktif dan langsung. Oleh karena itu, untuk ke depannya model pembelajaran Learning Cycle haruslah lebih dipelajari agar semakin mudah dalam menerapkan kepada siswa.

Selanjutnya untuk rata-rata hasil belajar siswa yang dibelajarkan dengan Konvensional lebih rendah dibandingkan dengan model pembelajaran yang lain (Learning Cycle dan Problem Based Learning). $\mathrm{Hal}$ ini disebabkan penggunaan Konvensional yang masih sederhana. Dalam pengajaran konvensional, siswa dalam proses pengajaran dipandang sebagai orang yang belum mengetahui apaapa dan hanya menerima bahan-bahan ilmu pengetahuan yang diberikan guru. Tujuan pembelajaran konvensional adalah terbatas pada pemikiran ilmu pengetahuan sehingga siswa berperan pasif ketika proses belajar mengajar berlangsung dan siswa cenderung menerima keputusan guru dalam pengajaran yang diberikan oleh guru. Maka hasil belajar pun akan memberikan rata-rata yang berbeda signifikan bila dibandingkan dengan ratarata hasil belajar siswa yang dibelajarkan dengan menggunakan model pembelajaran.

\section{KESIMPULAN}

Berdasarkan hasil penelitian yang telah diuraikan, maka diperoleh kesimpulan bahwa: Terdapat pengaruh model pembelajaran (Learning Cycle, Problem Based Learning, dan Konvensional) terhadap hasil belajar siswa pada materi ekosistem.

\section{DAFTAR PUSTAKA}

Akcay, B. 2009. Problem-Based Learning in Science Education. Journal of Turkish Science Education. 6(1): 26-36.

Arends. 2008. Learning To Teach: Belajar untuk Mengajar. Edisi Bahasa Indonesia. Edisi ketujuh. Yogyakarta: Pustaka Pelajar.

Dahar, R. 1988. Teori-Teori Pembelajaran. Jakarta: Erlangga.

Reyna, J. 2011. Digital Teaching and Learning Ecosystem (DTLE): A Theoretical Approach for Online Learning Environments. Proceedings ascilite 2011 Hobart: Concise Paper, Hobart, Tasmania, Australia, 4-7 Desember2011,(http://www.ascilite.org.au conferenceshobart11downloadspapersReyna -concise.pdf, diakses 6 Desember 2013).

Setiawan, I. G. A. N. 2008. Penerapan Pengajaran Kontekstual Berbasis Masalah untuk Meningkatkan Hasil Belajar Biologi Siswa Kelas $\mathrm{X}_{2}$ SMA Laboratorium 


\section{Situmorang / Jurnal Pendidikan Biologi 7 (1) (2017) 65 - 71}

Singaraja. Jurnal Penelitian dan Pengembangan Pendidikan Undiksha (online), (http://www.freewebs.com, diakses tanggal 14 Juni 2014).

Simmons, E.M., et.al. 2008. Assessing The Influence of Field-and Gis-Based Inquiry on Student Attitude and Conceptual Knowledge in an Undergraduate Ecology Lab. CBE-Life Science Education. 7: 338-345.

Sitepu, S. 2011. Pengaruh Strategi Pembelajaran Berbasis Masalah dan Motivasi Belajar terhadap Kemampuan Berpikir Kritis dan Hasil Belajar Biologi
Siswa SMA Negeri 1 Lubukpakam. Tesis, Program Pasca Sarjana Universitas Negeri Medan.

Suastika, K. 2011. Implementasi Model Pembelajaran Siklus (Learning Cycle) pada Pembelajaran Fisika Materi Dinamika Partikel di Kelas X Semester 1 SMA Negeri 1 Palangka Raya Tahun Ajaran 2010/2011. Prosiding Seminar Nasional Penelitian, Pendidikan dan Penerapan MIPA, Fakultas MIPA, Universitas Negeri Yogyakarta, 14 Mei 2011, diakses 6 Desember 2013. 